\title{
AIR PERMEABILITY AS A TEXTURAL INDICATOR OF SNOW
}

\author{
By H. Conway and J. Abrahamson
}

(Department of Chemical and Process Engineering, University of Canterbury, Private Bag, Christchurch, New Zealand)

Abstract. Two air-permeability devices were developed and measurements were made to study the relationship between air permeability and structure of different snow types. Permeabilities varied both with position and direction in the snow-pack, and changed with time as metamorphic changes occurred. A marked increase of air permeability was noted as faceted crystals grew due to radiation recrystallization. In other observations, as a snow-pack densified and crystals became more rounded (destructive metamorphism) the air permeability decreased. Measurements were made of air permeability of snows that had been subjected to a creeping tensile strain, and initial tests indicated that the changes in air permeability due to strain, even to rupture, were significant, but small compared with the intrinsic variability of snow.

RÉsumé. Perméabilité à l'air et texture de la neige. Deux perméamètres ont été conçus et réalisés pour étudier la texture de la neige. Dans un manteau neigeux la perméabilité varie d'un point à l'autre mais elle est également anisotrope et peut ėvoluer au cours du temps. Une augmentation sensible de la perméabilité à l'air est observée lors du développement de cristaux automorphes (métamorphose constructive); par contre lorsque la couche de neige se compacte et les cristaux s'arrondissent (métamorphose destructive)

\section{INTRODUCTION}

Gubler (1978) suggests that the tensile strength of snow is a function of snow texture rather than simply a function of density. Most descriptions of snow texture have been based on the analysis of thin sections (Good, [1975]; Kry, 1975; Narita, 1980) where parameters such as the type of grain, the area of bonds, the number of bonds per grain, and how these bonds link several grains together, were studied. Both Shimizu (1970) and Martinelli (1971) suggest that air permeability may also give an indication of snow texture. Field evidence by Martinelli (1971) shows that correlation with air permeability explains some of the scatter in the tensile strength/density relationship for snow. His data suggest that at any given density there is a certain texture or permeability of snow for which the tensile strength is a maximum.

Observations by Narita (1980) on samples that had been subjected to uniaxial tension show the formation of small cracks across the sample, perpendicular to the direction of deformation, when the strain-rate was not too small (greater than about $10^{-5} \mathrm{~s}^{-1}$, depending on the snow temperature and density). Narita also observed that bonds were preferentially cut rather than elongated, although at the lowest strainrates $\left(10^{-6} \mathrm{~s}^{-1}\right)$, the tensile deformation was thought to be associated with rearrangement of grains rather than crack formation.

Our measurements in this study were made to evaluate the usefulness of air permeability in characterizing snow texture. More specifically, our measurements of air permeability were:

1. on snow of various densities, grain type, and size; 2. on snow of similar age, density, and type so we could evaluate the intrinsic variability and independence of permeability from these measures, in a given snow-pack;

3. on snow where metamorphic change was apparent;

4. on snow that had been subjected to a creeping tensile strain, to determine whether cracks or bond elongation as observed by Narita (1980) could be detected with the technique. la perméabilité décroit. Sur des échantillons soumis à une traction, le fluage (jusqu'à la rupture) entraine une modification significative de la perméabilité à l'air. Mais cette modification est faible comparée aux variations intrinsèques de perméabilité de la neige.

Zusammenfassung. Lufldurchlässigkeit als ein Textur-Indikator von Schnee. Es wurden zwei Vorrichtungen zur Feststellung der Luftdurchlässigkeiten entwickelt und zum Stadium der Schneetextur benutzt. Die Durchlässigkeiten variierten sowohl mit der Lage wie mit der Ausrichtung in der Schneedecke und änderten sich zeitlich mit metamorphischen Vorgängen. Eine beträchtliche Zunahme der Durchlässigkeit trat ein, als facettierte Kristalle infolge von Rekristallisation durch Strahlung wuchsen. Bei anderen Beobachtungen nahm die Durchlässigkeit ab, wenn sich die Schneedecke verdichtete und die Kristalle gerundet wurden (destruktive Metamorphose). Die Luftdurchlässigkeit von Schnee, der einer kriechenden Zugspannung unterworfen wurde, wurde gemessen; Anfangsversuche zeigten, dass die Änderungen der Luftdurchlässigkeit infolge von Belastung, sogar bis zum Bruch, bedeutend sind, jedoch klein im Vergleich zur inneren Veränderlichkeit des Schnees.

The first portable air-permeability device used in these experiments relied on an air supply from a tank that was pressurized just before the test. Later we developed another smaller device with a hand-operated fan to provide an air flow.

\section{THE AIR PERMEOMETERS}

\section{The tank permeometer}

A schematic drawing of this device is shown in Figure 1. The four litre tank, which was pressurized to about $350 \mathrm{kPa}$ with a hand pump, was connected to a pressure gauge and a rapidly activated on/off valve. We could remove the sampling head from the device to sample a 0.3121 sample of snow. The head has a $1.1 \mathrm{~mm}$ diameter orifice at the base through which flowed air from the pressurized tank. The flow-rate was a function of gas temperature, tank pressure, and atmospheric pressure (i.e. corrected for altitude), (Conway and Abrahamson, unpublished [a]). A Dwyer inclined manometer $(0-80 \mathrm{~mm}$ water gauge with a resolution of $1 \mathrm{~mm}$ water) was connected to a tapping on the side of the head to enable us to measure the pressure drop over the sample. We made the sampling head from methylmethacrylate tubing to minimize heating from radiation (melting was observed when we used a metal sampler), and a rubber 0 -ring at the base of the sample guarded against edge leakage effects. Some glass fibre pads at the base of the head, dispersed

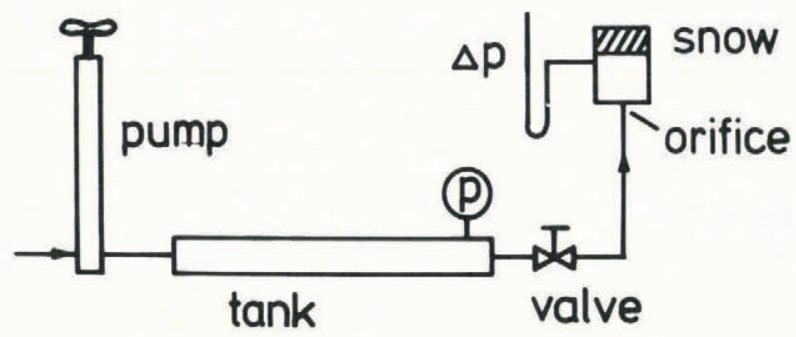

Fig. 1. Schematic drawing of the tank permeometer. 
the air flow through the sample and stopped venturi effects at the manometer tapping. The overall dimensions of the permeometer (excluding the pump) were $500 \mathrm{~mm} \times 350 \mathrm{~mm} \times 300 \mathrm{~mm}$ and the weight was $6.2 \mathrm{~kg}$.

\section{The blower permeometer}

A sketch of this device and a photograph are shown in Figure 2. This more portable device (weighing $1 \mathrm{~kg}$ ), was $280 \mathrm{~mm}$ long and $90 \mathrm{~mm}$ in diameter with a removable handle to drive the fan. We used two Dwyer (0-80 mm water gauge) inclined manometers, one to give us an estimate of air flow-rate (via pressure drop across an $8 \mathrm{~mm}$ diameter orifice below the fan), and the other to measure the pressure drop over the sample. The fan had a gearing of $1: 40$, and superficial air velocities of up to $90 \mathrm{~mm} \mathrm{~s}-1$ were possible. The vortex induced by the fan required an 8-bladed radial baffle system above the impellor to avoid vortex penetration to the pressure tapping just below the sample, and to disperse the air evenly through the sample. Again the sampler was made from methylmethacrylate tubing and the sample volume was 0.3631 .

\section{EXPERIMENTAL PROCEDURE}

We made most of the experiments described, on the upper Tasman Glacier (altitude $2100 \mathrm{~m}$ ) in the Mt Cook National Park over the New Zeal and 1981 and 1982 winters. This is a region of high snow-fall where storm cycles may typically deposit $0.3-1.5 \mathrm{~m}$ of generally dry snow with new-snow density in the range 40-

$250 \mathrm{~kg} / \mathrm{m}^{3}$. Winter snow-pack temperatures may vary from $-2^{\circ} \mathrm{C}$ to $-25^{\circ} \mathrm{C}$ and most slopes are glacially based. The area is noted for considerable wind strength and most snow-falls are associated with wind.

Our samples were cylindrical in shape and were generally taken with the axis perpendicular to the snow surface ( $Z$ direction) although some were taken with the axis parallel to the slope both up-slope ( $X$ direction), and across-slope ( $Y$ direction), to study the anisotropic natuie of the snow. We measured crystal size and type with a $14 x$ hand lens and grid, and used the classification system outlined by Sommerfeld and LaChapelle (1970) to describe the crystals. We also recorded density, snow temperature, slope profile, and angle at each site.

Darcy's law states for low velocities (in the laminar flow region), the rate of flow of a fluid through a bed of particles is directly proportional to the pressure gradient causing the flow. Thus, if a volumetric flow-rate $Q$ flows through a sample of cross-sectional area $A$ and length $L$ under a pressure difference $\Delta P$ between the ends, then:

$$
Q / A=\frac{B \Delta P}{L}
$$

where B is a constant (fluid permeability which is dependent on the properties of the fluid as well as the pore structure of the medium).

Some of the major experimental problems and effects of changing flowrates and sample size are discussed in a report by Conway and Abrahamson (unpublished [a]). That report showed that the permeability B did not change significantly with increasing flowrates within the range of flow-rates used (velocities of $50-100 \mathrm{~mm} / \mathrm{s}$ ), although the permeabilities measured were probably influenced by some turbulence within the snow pores, and could be up to $16 \%$ high compared with those for flow-rates expected in the strictly laminar regime (using the Ergun correlation - see Bird and others, 1960, p. 196-200). Conway and Abrahamson recorded about $27 \%$ reduction in permeability when using a smaller sample area (sample diameter reduced from $90 \mathrm{~mm}$ to $53.3 \mathrm{~mm}$ ), and they attributed most of the change to the higher range of velocities used with subsequent increased turbulent flow. They
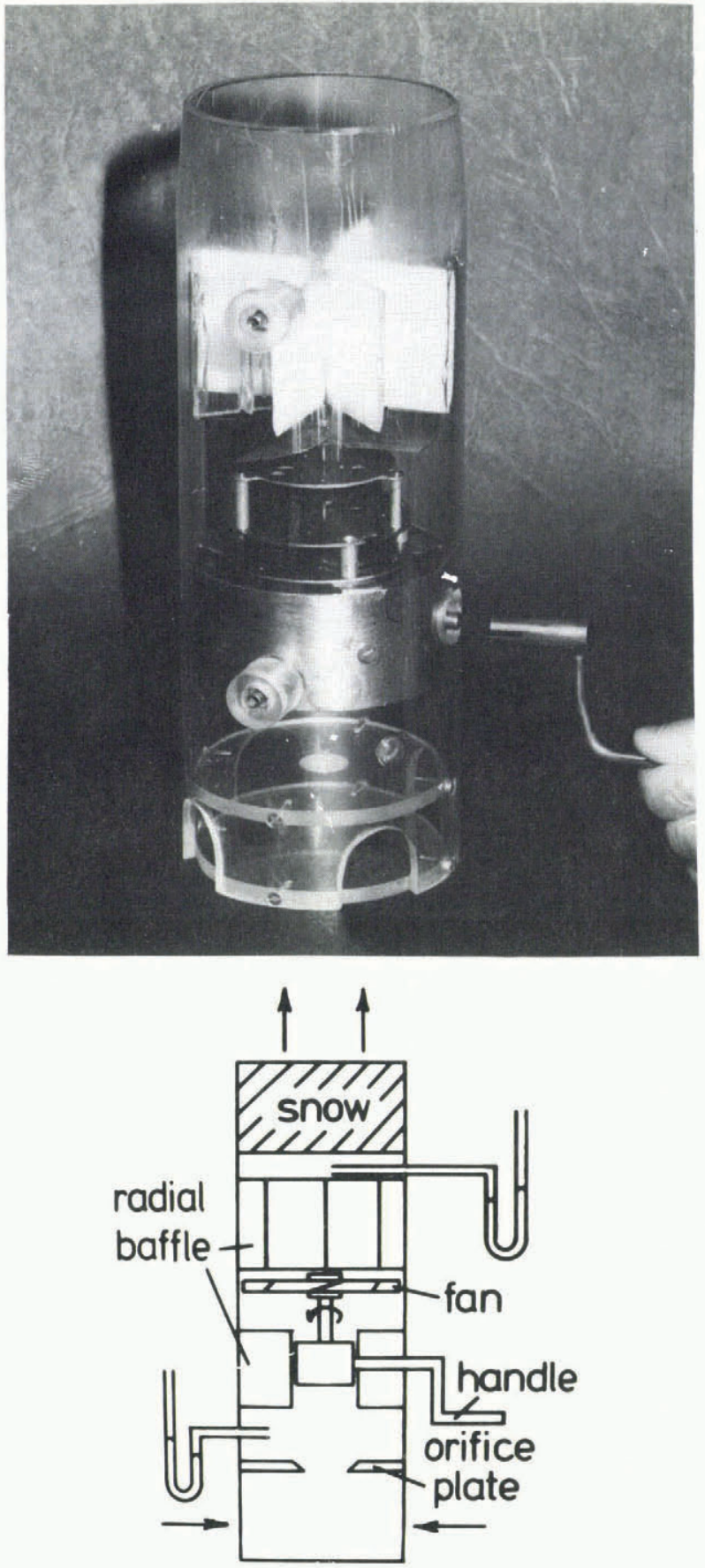

Fig. 2. A sketch and photograph of the blower air permeometer.

also included a calculation comparing the $53.3 \mathrm{~mm}$ diameter sample with the $90 \mathrm{~mm}$ diameter sample to determine the effect of wall leakage of air and concluded that this effect was small.

\section{RESULTS OF TESTS}

1. Air permeability-density relationship of snow The distribution of air permeability of snow of various types is given as a function of density in Figure 3, together with data from Shimizu (1970). We note a general agreement with Shimizu's measurements. As observed by Shimizu (1970) and Martinelli (1971), no unique relationship between air permeability and density could be found. 


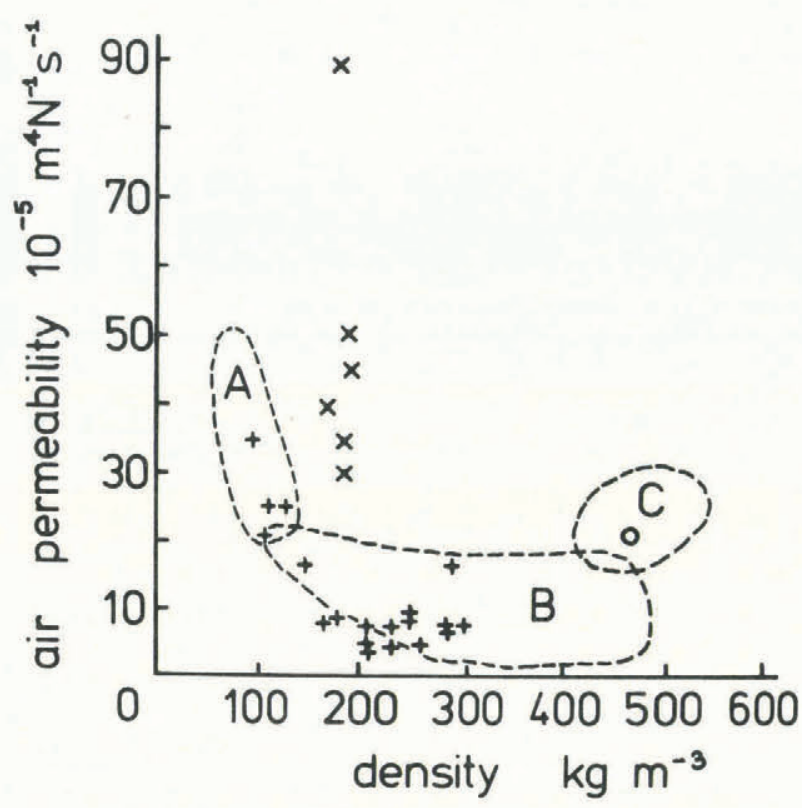

Fig. 3. Air permeability of snow of various types, compared with density. This study:

$x=$ temperature-gradient $(T G)$ snow, $+=$ finegrained snow (less than $1 \mathrm{~mm}$ ), $0=$ coarse-grained snow (2-5 mo). Broken lines from Shimizu (1970): $A=$ new snow, $B=$ fine-grained compacted snow, $C=$ coarse-grained snow.

2. Air permeability variability of snow of similar age and type

Perla (1978) suggested density variations of at least $10 \%$ in wind-deposited snow, and we recorded considerable variation of snow strengths (at the same site and time) on the slopes of the upper Tasman Glacier during the 1981 and 1982 winters.

At several sites, we took samples in the $X, Y$, and $Z$ directions and recorded direction-to-direction variations of up to $20 \%$ of the mean permeability. We analysed the data statistically by comparing the difference of the means in each direction with the pooled error standard deviation. The difference of permeability in the $X$ and $Y$ directions was not always significant, but the mean air permeability of snow measured in the $Z$ direction was always significantly lower ( 0.01 level) than those measured in the $X$ or $Y$ directions. Care was taken to sample always within a layer of more than $90 \mathrm{~mm}$ depth, to avoid stratification. Repeated tests at the same site, sampling in the $Z$ direction, gave standard deviations of up to $15 \%$ of the mean air permeability of the snow. Although some of this variability may be from our experimental error (e.g. flow-rate readings, manometer readings, sample disturbance), we think that much of the scatter is due to the intrinsic variability of the snow.

3. Air permeability changes with metamorphic changes in the snow

We revisited several sites during times of noprecipitation and recorded the change of air permeability of the same layer. Some of these cases are summarized below. At each site at any time, we have 1 isted the number of readings taken $(n)$ and the standard deviation (SD) together with the mean permeability measurement. Snow types are classified after Sommerfeld and LaChapelle (1970).

1. Over a period of eight fine cold days (maximum screen air temperature $=-1.4^{\circ} \mathrm{C}$, minimum screen air temperature $=-9.4^{\circ} \mathrm{C}$ ), radiation recrystallization of snow just under a surface crust occurred.

At one site (slope $=10^{\circ}$, west aspect), crystal structure and size changed from 0.5-1 mm early temperature-gradient (TG) crystals to $1-2 \mathrm{~mm}$ TG crystals. Although the snow density did not alter $\left(190 \mathrm{~kg} / \mathrm{m}^{3}\right)$ and snow temperature remained at $-7.2^{\circ} \mathrm{C}$, the air permeability increased from $28.1 \times 10^{-5} \mathrm{nt}^{+1} \mathrm{~N}^{-1} \mathrm{~s}^{-1}$ $\left(S D=3.5 \times 10^{-5}, n=18\right)$ to $45.7 \times 10^{-5} \mathrm{nt}^{+} \mathrm{N}^{-1} \mathrm{~s}^{-1}$ $\left(S D=4.0 \times 10^{-5}, n=16\right)$.

At another site (slope $32^{\circ}$, south aspect) similar structure and size changes occurred on snow with a density of $174 \mathrm{~kg} / \mathrm{m}^{3}$ and temperature $-10^{\circ} \mathrm{C}$, and the air permeability increased from $33.2 \times 10^{-5} \mathrm{nt}^{+} . \mathrm{N}^{-1} \mathrm{~s}^{-1}$ $\left(S D=4.0 \times 10^{-5}, n=12\right)$ to $95.4 \times 10^{-5} n^{+} \mathrm{N}^{-1} \mathrm{~s}^{-1}$ $\left(\mathrm{SD}=9.3 \times 10^{-5}, \mathrm{n}=8\right)$. On this same surface snow, we measured a decrease of the mean shear strength (measured with a $0.09 \mathrm{~m}^{2}$ shear frame) from $380 \mathrm{~N} / \mathrm{m}^{2}$ to $218 \mathrm{~N} / \mathrm{m}^{2}$ over the same time period.

2. Similar weather conditions during another period of three fine days caused some faceted crystals to develop under a surface crust. The air permeability of the snow just below the surface crust increased from: $8.9 \times 10^{-5} \mathrm{n}^{+} \mathrm{N}^{-1} \mathrm{~s}^{-1}\left(\mathrm{SD}=0.6 \times 10^{-5}, \mathrm{n}=12\right)$ to $12.5 \times 10^{-5} \mathrm{nt}^{+} \mathrm{N}^{-1} \mathrm{~s}^{-1} \quad\left(\mathrm{SD}=1.0 \times 10^{-5}, \hat{n}=9\right)$ for an initial snow density of $240, \mathrm{~kg} / \mathrm{m}^{3}$ and snow temperature of $-20^{\circ} \mathrm{C}$.

3. Over another period of five days, a new snow layer near the surface changed from new snow, to equitemperature type snow, and finally to radiation-recrystallized snow. These trends are plotted in Figure 4 and show decreasing permeability with destructive metamorphism, and increasing permeability with constructive metamorphism.

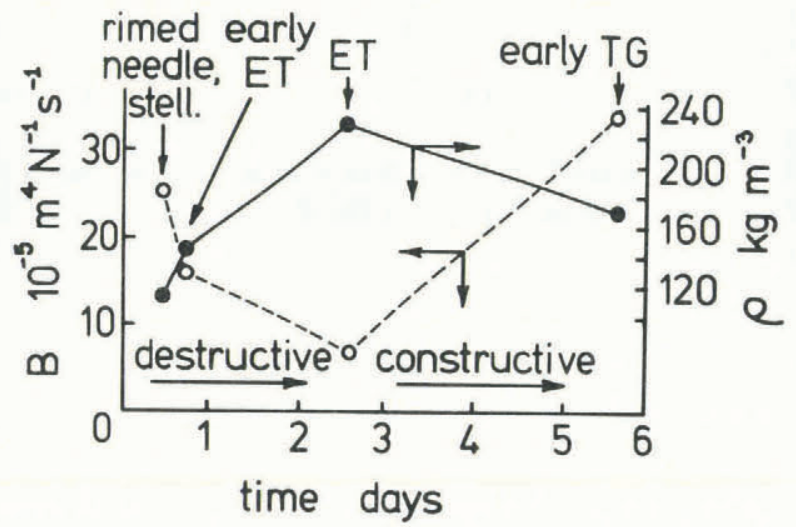

Fig. 4. Change of air permeability of snow with metamorphic changes. For about $2.5 \mathrm{~d}$ after the initial snow-fall of heavily rimed needle and stellar crystals, the snow temperatures were between $-0.5^{\circ} \mathrm{C}$ and $-3.8^{\circ} \mathrm{C}$. Equitemperature (ET) metamorphism and densification of the snow was rapid. Some fine cold weather over the next five days caused recrystallization of the surface snows (TG type snow) and the snow temperature lowered to $-6 \cdot 5^{\circ} \mathrm{C}$. Broken line is the permeability change; solid line is the density change.

4. Air permeability changes with tensile strain

We investigated the possibility that the variability of air permeability of snow is due to tensile strain causing localized cracks or crystal elongation, by comparing air permeability of snow that we had artificially strained, with similar snow that had not been strained. A device described by Conway and Abrahamson (unpublished [b]), strained a sample by pulling apart two aluminium plates which had been frozen onto the ends of the sample. The other technique we used for straining a sample was to isolate a snow column on a slope from effects of side-shear and compressive hold-up with saw cuts, also isolating it from effects of basal shear with a frictionless plate that we could slide under the column (see 


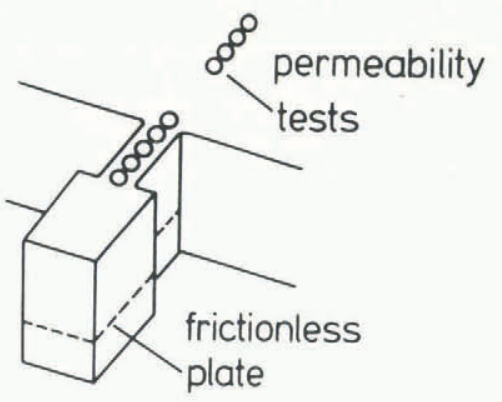

Fig. 5. One method used to strain a sample of snow on the slope to enable a comparison of air permeability of strained snow with that of undisturbed snow.

Fig. 5). The column could be left to creep from the gravity pull on the snow above the plate, or one could apply an additional force on the column by inserting some clamps on the sides of the column and pulling these with a calibrated spring; details of this are included in Conway and Abrahamson, 1984.

Average strain-rates between the end plates in the tensile tester were from $5.9 \times 10^{-5} \mathrm{~s}^{-1}$ to $1.3 \times 10^{-6} \mathrm{~s}^{-1}$. We were not always certain of the actual strain over the sample since we did observe some development and widening of cracks between the snow and the plates which would suggest that the strain within the sample would be smaller than the strain measured across the end plates. In other cases, the strain was measured between markers in the snow itself. Narita (1980) found that the strain at which visible cracks occurred in a sample under tension depended on the strain-rate as well as the snow properties, and in our tests, the strains were not sufficient to cause visible cracks. However, measurements of the air permeability of samples that had been strained in the tensile tester were significantly higher $(0.05$ confidence level) than air permeabilities of closely similar snow that had not been strained. Figure 6 shows the changes in permeability after strain as a function of the (tensile) strain. Our initial measurements appear to indicate an increase of permeability with increased strain, in line with the cracks observed by Narita (1980) at higher strains. More measurements are required to confirm this trend.

We did not measure strain over the columns of snow which were strained in situ (as in Figure 5), but we did find an increase of air permeability when we com-

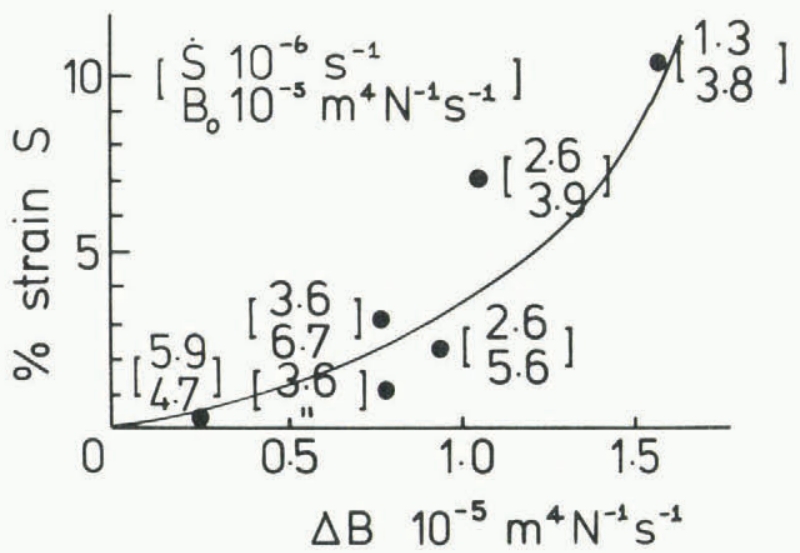

Fig. 6. A plot showing $\Delta B$, the increase of air permeability after strain, with strain. The average strain-rate and air permeability of snow that had not been strained are shown in brackets after each point.

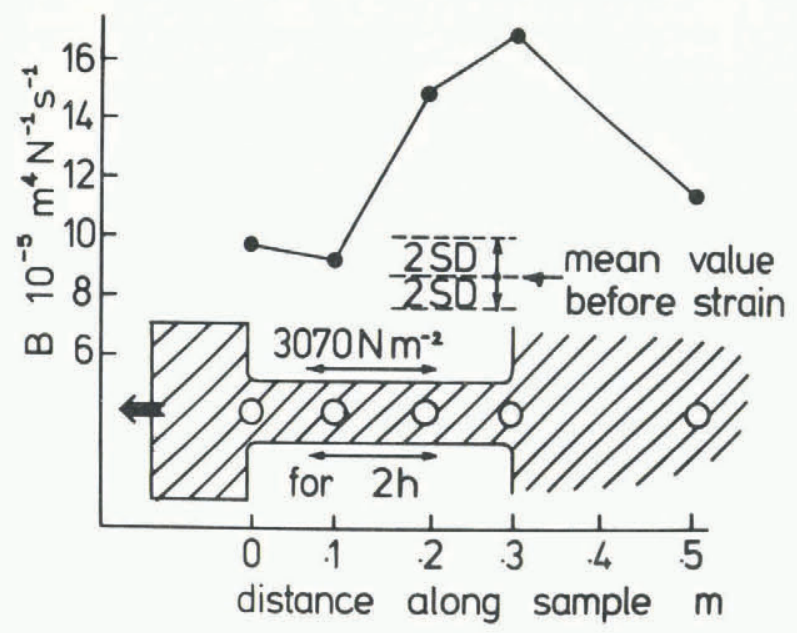

Fig. 7. A plot of the air permeability of snow up a column that had been strained for $2 h$ as shown in Figure 5 .

pared strained samples with undisturbed samples. One set of typical data is shown in Figure 7 .

5. Permeability changes with position on slopes We measured large differences of permeability (up to $300 \%$ ) down slopes in samples of similar age, density, temperature, crystal size, and type. Two examples of permeability measurements down slopes are shown in Figure 8 . We made a number of observations

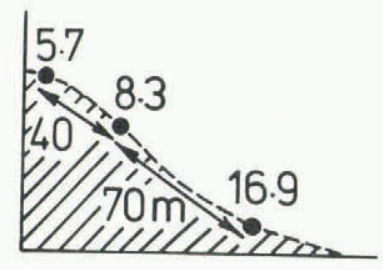

a

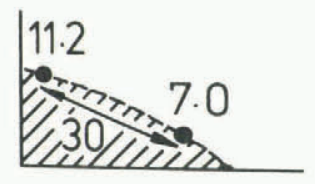

b

Fig. 8. (a) The change of air permeability of snow with position down the comice wall, 13 october 1981.

Top position: wind blown, $0.5 \mathrm{~mm}$ equitemperature (ET) type crystals, density $=270 \mathrm{~kg} / \mathrm{m}^{3} ; \mathrm{T}=-5.2^{\circ} \mathrm{C}$; slope angle $=20^{\circ} ; B=5.7 \times 10^{-5} \mathrm{~m}^{4} \mathrm{~N}^{-1} \mathrm{~s}^{-1}$ $\left(S D=0.5 \times 10^{-5}, n=18\right)$.

Middle position: wind blown $0.5 \mathrm{~mm}$ equitemperature (ET) type crystals, density $=240 \mathrm{~kg} / \mathrm{m}^{3} ; T=-7.0^{\circ} \mathrm{C}$; slope angle $=43^{\circ} ; B=8.3 \times 10^{-5} \mathrm{~m}^{4} \mathrm{~N}^{-1} \mathrm{~s}^{-1}$ $\left(S D=0.7 \times 10^{-5}, n=12\right)$.

Lower position: wind-blown $0.5 \mathrm{~mm}$ equitemperature (ET) type crystals, density $=270 \mathrm{~kg} / \mathrm{m}^{3} ; T=-5.5^{\circ} \mathrm{C}$; slope angle $=30^{\circ} ; B=16.9 \times 10^{-5} \mathrm{~m}^{4} \mathrm{~N}^{-1} \mathrm{~s}^{-1}$ $\left(S D=1.9 \times 10^{-5}, n=12\right)$.

(b) The change of air permeability of snow with position down the Nosedive, 23 June 1982.

Top position: 0.5 - $1 \mathrm{~mm}$ needles and broken stellar crystals, density $=150 \mathrm{~kg} / \mathrm{m}^{3} ; T=-8.0^{\circ} \mathrm{C}$; slope angle $=15^{\circ} ; B=11.2 \times 10^{-5} \mathrm{~m}^{4} \mathrm{~N}^{-1} \mathrm{~s}^{-1}$

$\left(S D=1.8 \times 10^{-5}, n=12\right)$.

Lower position: 0.5 - $1 \mathrm{~mm}$ needles and broken stellar crystals, density $=165 \mathrm{~kg} / \mathrm{m}^{3} ; \mathrm{T}=-8.0^{\circ} \mathrm{C}$;
slope angle $=30^{\circ} ; B=7.0 \times 10^{-5} \mathrm{~m}^{4} \mathrm{~N}^{-1} \mathrm{~s}^{-1}$

$\left(S D=0.5 \times 10^{-5}, n=11\right)$. 
at each site, and an analysis of the variation due to the change of site down the slopes showed the permeability between sites to be significantly different. Although the measurements were made on slopes that often avalanche, we did not observe instability of any of the slopes either before or after the measurements.

\section{DISCUSSION}

Often we found it difficult to sample a uniform layer due to the wind stratification of the snow, but once a layer had been isolated with a spatula, a homogeneous sample could be obtained. Care needed to be taken to keep the sampler aligned during sampling especially in the denser snows, which were more difficult to penetrate.

The first (tank) air permeometer was bulky and required considerable effort to pressurize the cylinder with the handpump. Sometimes the orifice partly blocked with snow or water and gave an erroneous airflow reading. A permeability measurement could be achieved with this device within about five minutes.

The blower air permeometer was less bulky and easier to operate, but the gear train (ratio $1: 40$ ) required for a reasonable air flow-rate was delicate and care had to be taken in keeping snow and grit out of the gears. The average time for a permeability measurement was less than one minute.

Scatter in our permeability-density plot was similar to that found by Shimizu (1970) (see Fig. 3). We also observed high variability of air permeability over small areas (less than $1 \mathrm{~m}^{2}$ ) and this suggests significant variation also of other snow properties over similar small areas (in particular snow strength). More measurements on closely similar samples are required before one could show whether or not any quantitative relationships between air permeability and strength exist.

One cause of the variations of snow-pack properties could be the depositional characteristics of wind-blown snow. The differences between measurements of air permeability in samples taken in different directions support this concept, as does the high variability of permeability measured within small areas. Several studies have measured periodic fluctuations in snow transport (e.g. Dyunin, 1967; Kobayashi, 1979), and have suggested that these could cause dunes in the snow. Again, more measurements are required to determine whether the variation of permeability is also periodic and related to this type of deposition.

Measurements on columns of snow that had been strained (Fig. 7), showed not only a significant increase of permeability after strain, but also a much higher scatter. If the increase of permeability is closely related to crystal elongation or cracks formed due to strain, then the high variations of permeability that we measured within the strained sample would support the evidence of Singh and Smith (1980), who found non-uniform strain along samples that had been subjected to a tensile stress.

The large variations of air permeability measured down slopes (Fig. 8), were probably caused by several factors. If the changes were related solely to strain, one might expect to observe high permeability in the tensile zone of a snow slab that is creeping, and relatively lower permeabilities in the neutral and compressive zones. Since the trends we observed on most slopes (four out of the five investigated), were different from this, we suspect that the depositional characteristics (or subsequent metamorphic changes) caused much of the variation. These influences made it difficult to gauge the importance of differential creep on the air permeability at different positions down slopes, especially as the slopes investigated were relatively stable (no avalanches occurred before or soon after testing).

\section{CONCLUSIONS}

Air permeability appears to be a useful parameter to give an indication of snow texture, and we developed a small hand-operated permeometer to make rapid field measurements of the air permeability of snow.

We found air permeability to be strongly dependent on metamorphism of the snow, and an increase of permeability appeared to be associated with constructive metamorphism, and a decrease of permeability with destructive metamorphism. We also found a small, but significant increase of permeability after samples had been subjected to tensile strain. We have insufficient data to know whether we could use this technique to identify early stages of run-away creep in a snow-pack, which may lead to instability.

We suggest that a decrease of permeability over a period of time on similar snows is a stabilizing trend in the snow-pack (either due to bond formation and/or destructive metamorphism of the snow), and an increase of permeability over a period of time is a sign of increasing instability (either due to bond elongation or bond breaking due to strain and/or constructive metamorphism of the snow).

\section{ACKNOWLEDGEMENTS}

Financial support for the study came from the Department of Lands and Survey (Wellington, New Zealand), University of Canterbury (Christchurch, New Zealand), Mountain Safety Council of New Zealand, and Mt Hutt Ski Company. Mt Cook Airlines Company provided aircraft access to the field area, and the Mt Cook National Park Staff were invaluable in their assistance with the field experiments. The Department of Chemical and Process Engineering (University of Canterbury), sponsored the project and helped develop the concepts and test equipment for the project.

\section{REFERENCES}

Bird, R.B., and others. 1960. Transport phenomena. By R.B. Bird, W.E. Stewart, and E.N. Lightfoot. New York, John Wiley and Sons, Inc.

Conway, H., and Abrahamson, J. 1984. Snow stability index. Journal of Glaciology, Vol. 30, No. 106, p. $321-7$.

Conway, H., and Abrahamson, J. Unpublished [a]. Air permeability as a measure of snow structure. Final report, part 3, for the New Zealand Mountain Safety Counci1. [Produced 1982.]

Conway, H., and Abrahamson, J. Unpublished [b]. In situ tests of large volumes of snow. Final report, part 1, for the New Zealand Mountain Safety Council. [Produced 1982.]

Dyunin, A.K. 1967. Fundamentals of the mechanics of snow storms. (In Oura, H., ed. Physics of snow and ice: intemational conference on low temperature science. . . 1966... .Proceedings, Vol. 1, Pt. 2. [Sapporo], Institute of Low Temperature Science, Hokkaido University, p. 1065-73.)

Good, W. [1975.] Numerical parameters to identify snow structure. [Union Géodésique et Géophysique Internationale. Association Internationale des Sciences Hydrologiques. Commission des Neiges et Glaces. ] Symposium. Mécanique de la neige. Actes du colloque de Grindelwald, avril 1974, p. 91102. (IAHS-AISH Publication No. 114.)

Gubler, H. 1978. An alternate statistical interpretation of the strength of snow. Journal of Glaciology, Vol. 20, No. 83, p. 343-57.

Kobayashi, S. 1979. Studies on interaction between wind and dry snow surface. Contributions from the Institute of Low Temperature Science, Hokkaido University (Sapporo), Ser. A, No. 29.

Kry, P.R. 1975. The relationship between the viscoelastic and structural properties of fine-grained snow. Journal of Glaciology, Vol. 14, No. 72, p. 479-500. 
Martinelli, M.,jr. 1971. Physical properties of alpine snow as related to weather and avalanche conditions. U.S. Dept. of Agriculture. Forest Service. Research Paper RM-64.

Narita, H. 1980. Mechanical behaviour and structure of snow under uniaxial tensile stress. Journal of Glaciology, Vol. 26, №. 94, p. 275-82.

Perla, R.I. 1978. Failure of snow slopes. (In Voight, B., ed. Rockslides and avalanches. 1. Natural phenomena. Amsterdam, etc., El sevier Scientific Publishing Co., p. 731-52. (Developments in Geotechnical Engineering, 14A.)
Salm, B. 1982. Mechanical properties of snow. Reviews of Geophysics and Space Physics, Vol. 20, No. 1, p. 1-19.

Shimizu, H. 1970. Air permeability of deposited snow. Contributions from the Institute of Low Temperature Science, Hokkaido University (Sapporo), Ser. A, No. 22.

Singh, H., and Smith, R.W. 1980. Constant strain-rate tensile testing of natural snow. Journal of Glaciology, Vol. 26, №. 94, p. 519. [Abstract.]

Sommerfeld, R.A., and LaChapelle, E.R. 1970. The classification of snow metamorphism. Journal of Glaciology, Vol. 9, №. 55, p. 3-17.

MS. received 1 August 1983 and in revised form 17 october 1983 